\title{
PENGALAMAN PEROKOK DALAM TERAPI BERHENTI MEROKOK DENGAN METODE SPIRITUAL EMOTIONAL FREEDOM TECHNIQUE (SEFT) DI DESA CIPANJALU KABUPATEN BANDUNG TAHUN 2019
}

\author{
Ejeb Ruhyat \\ Program Studi Sarjana Kesehatan Masyarakat STIKes Dharma Husada \\ eruhyat@yahoo.com
}

\begin{abstract}
Cigarettes and smoking are problems that are still difficult to resolve to date. About 4.9 million people in developing countries died of smoking in 2003. This study aimed to determine the experience of smokers in smoking cessation therapy with the Spiritual Emotional Freedom Technique (SEFT) method in Cipanjalu Village, Bandung Regency in 2019. The type of research conducted was The type of research used is qualitative research with a phenomenological approach. Informants in this study were smokers who had been treated as many as 4 people.

The results showed Based on the response or reaction when smoking cessation therapy was found that the reaction was almost the same, based on the desire to smoke after smoking cessation therapy that found all experienced a decrease in desire to smoke again, based on the length of time they did not smoke after different therapies - difference, Based on the number of cigarettes smoked after stopping smoking therapy, it was found that the number of cigarettes smoked every day varied after treatment, but all said they experienced a decrease in the number of cigarettes smoked. It is recommended to create a smoke-free environment with a shared commitment in the $R W$ to create a non-smoking environment.
\end{abstract}

Keywords $\quad$ : Smoker Experience, Therapy for Quitting Smoking, SEFT Method

\begin{abstract}
ABSTRAK
Rokok dan merokok merupakan masalah yang masih sulit diselesaikan hingga saat ini. Sekitar 4,9 juta orang di Negara berkembang meninggal dunia karena rokok pada tahun 2003. Penelitian ini bertujuan untuk mengetahui pengalaman Perokok dalam terapi berhenti merokok dengan metode Spiritual Emotional Freedom Technique (SEFT) di Desa Cipanjalu Kabupaten Bandung Tahun 2019. Jenis penelitian yang dilakukan adalah Jenis penelitian yang digunakan adalah penelitian kualitatif dengan pendekatan fenomenologi. Informan dalam penelitian ini yaitu perokok yang sudah dilakukan terapi yaitu sebanyak 4 orang.

Hasil penelitian menunjukan Berdasarkan respon atau reaksi saat dilakukan terapi berhenti merokok ditemukan bahwa adanya reaksi yang hampir sama, Berdasarkan keinginan merokok setelah dilakukan terapi berhenti merokok bahwa ditemukan semuanya mengalami penurunan rasa keinginan untuk merokok kembali, Berdasarkan lama lama bertahan tidak merokok setelah di terapi berbeda-beda, Berdasarkan jumlah batang rokok yang dihisap setelah dilakukan terapi berhenti merokok bahwa ditemukan jumlah batang rokok yang di hisap setiap hari berbeda-beda setelah terapi, tetapi semuanya mengatakan mengalami penurunan dalam jumlah batang rokok yang di hisap. Disarankan untuk membuat lingkungan bebas asap rokok dengan adanya komitmen bersama di lingkungan RW untuk membuat kawasan lingkungan bebas asap rokok.
\end{abstract}

Kata Kunci $\quad$ : Pengalaman Perokok, Terapi Berhenti Merokok, Metode SEFT

Jurnal Penelitian Kesehatan STIKes Dharma Husada Bandung 


\section{PENDAHULUAN}

Rokok dan merokok merupakan masalah yang masih sulit diselesaikan hingga saat ini. Berbagai dampak dan bahaya merokok sebenarnya sudah dipublikasikan kepada masyarakat, namun kebiasaan merokok masyarakat masih sulit untuk dihentikan. Dalam rokok terkandung tidak kurang dari 4000 zat kimia beracun. Ironisnya para perokok sebenarnya sudah mengetahui dampak dan bahaya dari merokok, namun masih tetap saja melakukan aktivitas tersebut. Mengapa orang sulit berhenti merokok? Nicotine regulation model menjelaskan bahwa pecandu rokok mempertahankan tingkat nikotin yang ada di dalam darahnya dan menghindari efek gejala putus zat ${ }^{1}$. Interaksi dua arah antara pengaruh nikotin pada otak yang kemudian menimbulkan efek psikologis, seperti penurunan kemampuan mengenali emosi dan kecenderungan depresi, membuat para pecandu rokok terus merokok agar tetap semangat dan lebih tenang ${ }^{1}$.

Data Badan Kesehatan Dunia (WHO) memperlihatkan bahwa jumlah pecandu rokok di Indonesia cenderung meningkat. Nikotin yang terkandung dalam rokok digolongkan sebagai zat adiktif yang peredarannya harus diawasi secara ketat seperti alcohol ${ }^{1}$. Walau demikian, produksi rokok cenderung naikdari tahun ke tahun. Dalam sebuah publikasi WHO tahun 2004 bertajuk Tobacco and Poverty: A Vicious Cycle dikatakan bahwa ada beberapa cara dimana tembakau meningkatkan kemiskinan di tingkat individu, rumah tangga dan tingkat nasional ${ }^{2}$.

Tren pengeluaran untuk tembakau diantara orang-orang miskin dibeberapa negara berkembang sangat mengkhawatirkan. Di Indonesia misalnya, pengeluaran tembakau memiliki pertumbuhan yang cukup cepat pada kelompok masyarakat miskin. Pada tahun 1981, kelompok berpenghasilan terendah menghabiskan $\mathrm{Rp}$ 210,- per kapita untuk tembakau, 9\% dari total pengeluaran mereka. Hal ini naik menjadi Rp 1.278,- atau $15 \%$ dari total pengeluaran pada tahun 1996 (estimasi World Bank dengan menggunakan statistik yang diterbitkan oleh BPS). Dibutuhkan upaya yang lebih besar untuk mengurangi penggunaan tembakau di kalangan masyarakat miskin ${ }^{2}$.

Sekitar 4,9 juta orang di Negara berkembang meninggal dunia karena rokok pada tahun 2003. Bahkan di seluruh dunia, tingkat kematian akibat rokok justru lebih besar daripada kematian karena malaria, kematian maternal, penyakit-penyakit yang sering menyerang anak-anak dan tuberculosis. Ahli kesehatan dunia memperkirakan tahun 2030 sekitar 10 juta orang mati akibat rokok dan 70 persen terjadi di Negara berkembang. Indonesia termasuk 5 negara dengan konsumsi rokok terbesar di dunia. Konsumsi tembakau di Indonesia meningkat 7 kali lipat dalam jangka waktu 3 tahun (1997-2000) dan prevalensi penggunaan tembakau di Indonesia telah 
meningkat dalam segala usia ${ }^{3}$.

Proporsi penduduk umur lebih dari 10 tahun menurut kebiasaan merokok di Indonesia tahun 2013 menunjukan proporsi terbanyak perokok aktif pada umur 30 - 34 tahun sebesar $33.4 \%$, umur 35 - 39 tahun sebanyak $32,2 \%$ sedangkan proporsi perokok setiap hari laki-laki lebih banyak dibandingkan perokok perempuan $(47.5 \%$ banding $1.1 \%$ ). Berdasarkan jenis pekerjaan, petani/nelayan/buruh adalah proporsi perokok aktif setiap hari yang terbesar (44.5\%) dibandingkan kelompok pekerja lainnya. Jika dilihat dari proporsi Provinsi jumlah perokok setiap hari posisi tertinggi berada di wilayah kepulauan Riau dengan jumlah perokok perokok setiap hari sebanyak 27,2 \%, sedangkan posisi terendah berada di provinsi Papua sebesar 16,3\%, ${ }^{4}$.

Berdasarkan jumlah batang rokok yang dihisap penduduk umur $\geq 10$ tahun menurut provinsi posisi tertinggi berada di provinsi Bangka Belitung sebesar 18,3\%, sedangkan posisi terendah berada di provinsi Yogyakarta sebesar $9,9 \%{ }^{4}$.

Penanggulangan masalah rokok di Indonesia memang sangat dilematis. Disatu sisi industri rokok dianggap sebagai penghasil pajak paling besar dibandingkan dengan sektor lain. Misalnya, dapat memberikan kontribusi terhadap pemasukan keuangan Negara berupa pembayaran cukai.Singkat kata, industri rokok adalah industri padat karya dan memberikan sumbangan yang cukup besar dalam perekonomian bangsa. Meski keberadaanya memegang peranan penting bagi kehidupan masyarakat, tetapi banyak penyakit yang ditimbulkan akibat merokok .Penyakit tersebut merupakan penyebab kematian utama $^{2}$.

Pada tingkat individu dan rumah tangga, uang dihabiskan untuk tembakau yang memiliki opportunity cost yang sangat tinggi. Bagi masyarakat miskin, uang dihabiskan untuk tembakau bukan dibelanjakan untuk kebutuhan pokok, seperti makanan, tempat tinggal, pendidikan dan kesehatan. Tembakau berkontribusi terhadap kemiskinan individu dan keluarga karena pengguna tembakau memiliki risiko lebih tinggi untuk jatuh sakit dan mati muda akibat kanker, serangan jantung, penyakit pernapasan atau penyakit yang berkaitan dengan tembakau lainnya, sehingga merampas pendapatan yang sangat dibutuhkan keluarga dan tambahan biaya perawatan kesehatan yang besar ${ }^{2}$.

Efek negatif rokok tidak hanya pada penggunanya saja, asap rokok yang dihembuskan oleh perokok berdampak sama buruknya bagi si bukan perokok, atau orang yang berada disekitarnya sebagai perokok pasif. Sehingga dapat dibayangkan efek multiplikasi dari sebatang asap rokok yang dihisap oleh perokok yang dihirup oleh orang banyak disekitarnya ${ }^{5}$.

Target cakupan Perilaku Hidup Bersih dan Sehat (PHBS) Rumah Tangga tahun 2014, ditetapkan dalam Rencana Strategi (Renstra) Kementrian Kesehatan RI sebesar 
70\% (kemenkes RI, 2011). Namun hasil Riskesdas tahun 2013 menunjukan bahwa proporsi nasional Rumah Tangga dengan PHBS baik hanya sekitar $32,3 \%{ }^{4}$. Presentase rumah tangga yang mempraktikkan PHBS rumah tangga dengan baik sebesar 32,3\%. Berdasarkan proporsi RumahTangga dengan indikator tidak merokok didalam rumah 78,8\%. Sedangkan berdasarkan Proporsi Rumah Tangga yang memenuhi kriteria Perilaku Hidup Bersih dan Sehat (PHBS) baik menurut propinsi, posisi tertinggi propinsi DKI Jakarta 56,8\% dan terendah propinsi Papua 16,4\%. Hal tersebut menunjukkan bahwa perilaku merokok masyarakat masih sangat tinggi.

Hasil kegiatan Pengalaman Belajar Lapangan (PBL) Mahasiswa Prodi Sarjana Kesehatan Masyarakat di desa Cipanjalu menunjukkan bahwa perilaku merokok menempati urutan pertama dari data Indek Keluarga Sehat dan Perilaku Hidup Bersih dan Sehat. Hasil kegiatan PBL selama 2 tahun berturut-turut, yaitu tahun 2018 dan 2019 menunjukan bahwa perilaku merokok masih tetap menjadi yang tertinggi. Pada tahun 2018 menunjukan sebesar 18,9\% masyarakat tidak merokok didalam rumah dan pada tahun 2018 sebesar 19,4 \% tidak merokok di dalam rumah. ${ }^{6,7}$

Berdasarkan data diatas, terlihat ada penurunan angka perilaku merokok didalam rumah, namun penurunannya tidak signifikan, hanya $1,5 \%$ terjadi penurunan perilaku merokok pada masyarakat Desa Cipanjalu
Kecamatan Cilengkrang Kabupaten Bandung. Kabupaten Bandung pada tanggal 28 Desember 2017 telah mensosialisasikan Peraturan Daerah (Perda) Kawasan Tanpa Rokok (KTR) Nomor 13 tahun 2017 yang berisi tentang, Kawasan Tanpa Rokok (KTR) adalah Ruangan atau area yang dinyatakan dilarang untuk kegiatan merokok atau kegiatan memproduksi, menjual, mengiklankan dan / atau mempromosikan produk tembakau, oleh karena itu semua tempat yang telah ditetapkan sebagai Kawasan Tanpa Rokok (KTR) harus bebas dari asap rokok, penjualan, produksi, promosi dan sponsor rokok. ${ }^{8}$

Di Kabupaten Bandung Pada tahun 2017 sudah dilakukan Pelatihan berhenti merokok kepada seluruh Petugas Kesehatan Pemegang Program Promosi Kesehatan (Promkes) dengan model Pelatihan Terapi Tobat Rokok metode Spiritual Emotional Freedom Technique (SEFT), namun sampai saat ini belum diaplikasikan secara optimal. ${ }^{7}$

Pada Kegiatan Pengalaman Belajar Lapangan (PBL) Program Studi Sarjana Kesehatan Masyarakat, mencoba menerapkan Terapi berhenti merokok tersebut dengan bimbingan dan pengawasan dari Puskesmas Cilengkarang.

Peneliti tertarik melakukan Penelitian "Pengalaman Perokok dalam terapi berhenti merokok dengan metode Spiritual Emotional Freedom Technique (SEFT) di Desa Cipanjalu Kabupaten Bandung Tahun 2019”. Tujuan Penelitian ini adalah Untuk 
melakukan Explorasi tentang pengalaman Perokok dalam terapi berhenti merokok dengan metode Spiritual Emotional Freedom Technique (SEFT) di Desa Cipanjalu Kabupaten Bandung Tahun 2019.

\section{METODOLOGI PENELITIAN}

Jenis penelitian yang digunakan adalah penelitian kualitatif dengan pendekatan fenomenologi yaitu peneliti mencoba memahami subjek dari sudut pandang subjek sendiri, baik tentang penyebab, tanda dan gejala, maupun dampak yang ditimbulakannya serta cara mengatasinya. Menurut Moleong, penelitian kualitatif adalah penelitian yang bermaksud memahami fenomena tentang apa yang dialami oleh subjek peneliti, persepsi, motivasi, tindakan. Sedangkan menurut Sugiyono, metode penelitian kualitatif yaitu metode penelitian yang digunakan untuk meneliti pada kondisi objek yang alamiah, dimana peneliti adalah sebagai instrumen kunci, teknik pengumpulan data dilakukan secara triangulasi (gabungan), analisa data bersifat induktif/kualitatif, dan hasil penelitian kualitatif lebih menekankan makna daripada generalisasi. ${ }^{13,14}$

Metode penelitian kualitatif bisa menggali informasi secara mendalam dan rinci tentang apa yang diinginkan oleh peneliti. Metode penelitian kualitatif untuk meneliti topik tentang Pengalaman Perokok dalam terapi berhenti merokok dengan metode Spiritual Emotional Freedom Technique (SEFT) di Desa Cipanjalu Kabupaten Bandung
Tahun 2019.

Subjek penelitian sering disebut juga sebagai informan penelitian. Penentuan sampel pada penelitian ini peneliti menggunakan teknik pusposive sampling yaitu sampel penelitian diambil sesuai dengan kriteria yang sudah ditentukan sebelumnya. Informan dalam penelitian ini yaitu perokok yang sudah dilakukan terapi yaitu sebanyak 4 orang. Adapun masing-masing informan dilakukan indept intervieu (Wawancara Mendalam) antara 15-30 menit.

Metode pengumpulan data yang digunakan adalah wawancara mendalam, yang diharapkan peneliti akan mengetahui hal-hal yang lebih mendalam tentang informan dalam menginterprestasikan situasi dan fenomena yang terjadi, dimana hal ini tidak bisa ditemukan melalui observasi (Susan Stainback 1988, dalam Sugiyono 2010). ${ }^{14}$

Adapun pelaksanaannya menggunakan alat bantu rekaman berupa tape recorder/MP 4 dan dicatat secara langsung hal-hal intinya. Waktu pelaksanaanya dilaksanakan setelah kesepakatan terlebih dahulu dengan informan untuk menjaga kerahasiaanya. Adapun metodenya yaitu dengan indept intervieu (wawancara mendalam). Tujuannya adalah guna mendapakan informasi yang lebih lengkap dan mendalam. Format wawancara mengacu kepada kerangka atau panduan wawancara yang telah disiapkan oleh peneliti. Wawancara dinyatakan selesai dilaksanakan sampai informan mengalami titik jenuh. Artinya informan tersebut dilakukan 
wawancara oleh peneliti sampai tidak bisa menjawab pertanyaan-pertanyaan selanjutnya yang diajukan oleh peneliti dan tidak ada katakata lain untuk menjawab pertanyaan dari peneliti.

Instrumen penelitian yang digunakan adalah human instrument/peneliti sendiri. Namun pada pelaksanaan penelitian, peneliti dibantu oleh beberapa kader dan mahasiswa. ${ }^{14}$

Analisa data yang digunakan pada penelitian kualitatif adalah analisis data model Miles dan Huberman (Sugiyono, 2010). Adapun model analisis data tersebut terlihat di bagan $3.1 .^{14}$

\section{Bagan 3.1. Menentukan Analisis Data}

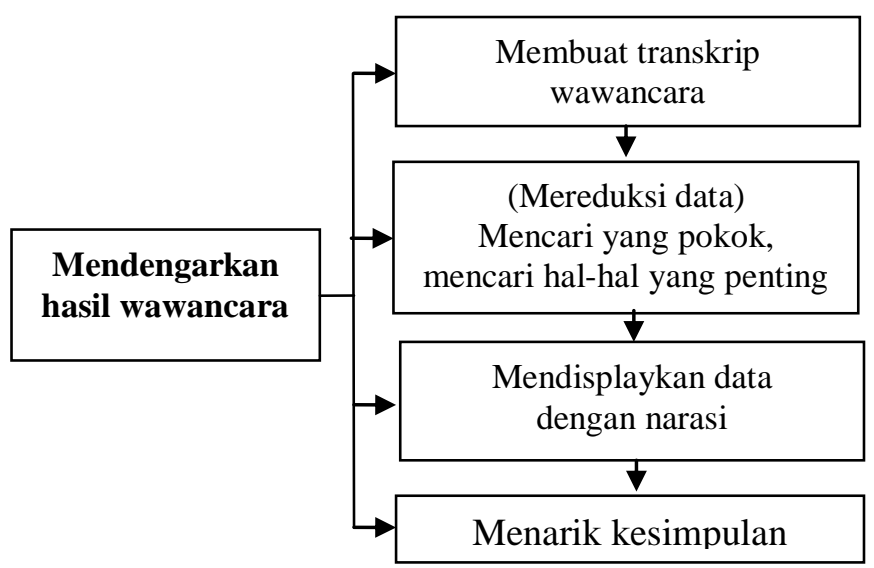

Sumber : Miles and Huberman (dalam Sugiyono 2010

Analisis data penelitian, pertama mengumpulkan data dengan wawancara mendalam kepada informan, merekamnya dan mencatatnya secara langsung. Kemudian mendengarkan hasil wawancara mendalam yang telah direkam, menyalinnya kembali dengan membuat transkrif untuk memperoleh pemahaman dari data yang telah terkumpul. Kemudian mereduksi data yang berarti merangkum data, mencari yang pokok, mencari hal-hal yang penting dengan menandainya dan mencari tema yang terdiri dari aktivitas.

Data yang telah direduksi kemudian didisplaykan atau disebut dengan penyajian data. Dengan mendisplaykan data akan mempermudah dalam memahami data.

Data yang terkumpul perlu diuji Keabsahannya. Keabsahan data adalah data yang memenuhi nilai kebenaran, dapat diterapkan, konsisten dan memenuhi unsur netralis bukan persepsi peneliti (Maleong). Uji keabsahan data meliputi uji derajat kepercayaan data (Credibility), Keteralihan data (Transferability), Kebergantungan data (Dependability), dan Kepastian data (Comfirmability). ${ }^{13}$

Menurut Sugiyono (2010), pemeriksaan derajat kepercayaan data (Credibility) adalah bahwa data dari penelitian memiliki derajat kepercayaan yang dapat dipertanggungjawabkan dengan diperkuat kenyataan fakta penelitian yang dilakukan oleh peneliti, contohnya dengan melihat data informan. Uji credibility yang dilakukan dalam penelitian ini adalah dengan teknik triangulasi sumber. Teknik triangulasi sumber dilakukan kepada beberapa sumber yang bersangkutan dengan informan, yaitu anggota keluarga informan. ${ }^{13}$

Keteralihan data (Transferability) adalah hasil penelitian dapat diterapkan dan digunakan dalam situasi lain, dimana lebih ditekankan kepada bagaimana orang lain 
dapat memahami hasil penelitian.

Transferability dilakukan dengan cara laporan penelitian yang dibuat secara rinci, jelas, sistematis, dan dapat dipercaya, sehingga orang lain dapat memahami hasil penelitian.

Ketergantungan data (Dependability) adalah valid tidaknya suatu data yang diperoleh bergantung dari kualitas peneliti sebagai instrument penelitian. Depenability dilakukan dengan cara peneliti melakukan penelitian penelitian sendiri dan tidak diwakilkan kepada orang lain.

Kepastian data (Comfirmability) adalah hasil penelitian telah disepakati banyak orang. Comfirmability dilakukan dengan cara peneliti melakukan konsultasi dengan ahli.

Penelitian ini dilaksanakan pada bulan Januari-Februari tahun 2019. Hal-hal yang dilakukan peneliti untuk menjaga etika penelitian yaitu :

a. Memberikan penjelasan maksud dan proses penelitian yang akan dilakukan kepada informan

b. Meyakinkan informan terlindungi dengan memperhatikan aspek kebebasan untuk menentukan apakah informan bersedia atau tidak untuk memberikan informasi yang dibutuhkan dalam penelitian

c. Secara sukarela menandatangani informed consent (lembar persetujuan untuk dijadikan informan)

d. Menjaga kerahasiaan identitas informan dan hanya digunakan untuk kegiatan penelitian saja e. Selama kegiatan penelitian informan diberlakukan sama, yaitu dengan mengganti nama informan dengan kode.

f. Selama pengambilan data, kenyamanan memberikan informasi oleh informan dijaga, dengan memilih ruang yang nyaman selama memberikan informasi

\section{HASIL PENELITIAN}

Berdasarkan hasil analisis data penelitian kualitatif yang berjudul Pengalaman Perokok dalam terapi berhenti merokok dengan metode Spiritual Emotional Freedom Technique (SEFT) di Desa Cipanjalu Kabupaten Bandung Tahun 2019, maka akan dibahas hasil penelitian tersebut berdasarkan pengalaman informan yang mendapatkan terapi berhenti merokok dari aspek respon yang dirasakan, faktor penghambat dan faktor pendorong.

Metode pengumpulan data dalam penelitian ini berdasarkan identitas informan. Pengambilan data dimulai tanggal 8-16 Februari 2019. Pengambilan data dilakukan di rumah informan dan di halaman kantor desa. Adapun waktu pengumpulan data disesuaikan dengan wktu kesediaan informan. Berikut adalah informan penelitian.

Tabel 1 Data Informan

\begin{tabular}{|c|c|c|c|}
\hline \multicolumn{2}{|c|}{ Identitas Informan Utama } & $\begin{array}{c}\text { Umur } \\
\text { (tahun) }\end{array}$ & Status \\
\cline { 1 - 2 } Inisial & Kode & 45 & Warga RW 06 \\
\hline Rh & 1A & 30 & Warga RW 02 \\
\hline UK & 1B & 40 & Warga RW 04 \\
\hline UJ & 1C & 48 & Warga RW 08 \\
\hline RW & 1D &
\end{tabular}

Hasil wawancara dengan informan mengenai Pengalaman Perokok dalam terapi 
berhenti merokok dengan metode Spiritual

Emotional Freedom Technique (SEFT) di Desa

Cipanjalu Kabupaten Bandung Tahun 2019.

\section{Respon/Reaksi Saat di Terapi}

"Merasa mual, pusing lalu disertai rasa ingin muntah...”... (Informan 1A)

"saya merasa sangat pusing, ingin muntah dan tenggorokan terasa sangat pahit, gak enak merokok"...... (Informan 1B)

"Iya baru merasa merokok gak enak, rasanya pahit dan serasa baru pertama merokok pada saat dulu merokok awal-awal sekali. Waktu di terapi totok sampai muntah"... (Informan 1C)

"iya de waktu itu pengen sekali bapak berhenti merokok, makanya bapk kesini mau diterapi trus rasanya pahit, dan mau muntah trus gak mau merokok lagi gak enak”... (Informan 1D)

Berdasarkan hasil wawancara didapatkan bahwa respon dari ke 4 informan di atas cenderung beragam. Hal tersebut terlihat dari jawaban informan, rata-rata informan menjawab merasakan pusing, mual, muntah walaupun kadarnya berbeda-beda. Reaksi yang sangat terlihat yaitu ketika informan muntah pada saat dilakukan terapi.

\section{Perubahan Keinginan Merokok setelah di Terapi}

"Merasa ragu ketika mau merokok lagi, kepikiran saja sepertinya rasa rokok tidak enak lagi”.. (Informan 1A)
"Rasa ingin merokok menurun, tetapi lihat temen ngerokok rasanya malu kalau tidak merokok, jadi ngerokok lagi. Walaupun awal merokok lagi masih kurang enak ".. (Informan 1B)

"Berkurang rasa keinginan merokok lagi, tetapi masih merasa aneh ketika tidak merokok ditambah cuaca dingin lagi hujan, jadi merokok lagi".. (Informan 1C)

"keinginan merokok selama sehari tidak mau sama sekali, pertama sudah niat, kedua masih inget dan masih kerasa rokok waktu diterapi tidak enak, pahit, tidak ada rasa takut muntah lagi”.. (Informan 1D)

Berdasarkan hasil wawancara dinyatakan bahwa dari ke 4 informan sebetulnya hampir sama. Keinginan untuk merokok kembali berkurang, mereka selalu teringat kejadian waktu di terapi. Bahkan ada yang bertahan hingga seharian tidak merokok. Walaupun pada akhirnya merokok lagi karena berbagai factor seperti: lingkungan pergaulan, cuaca dingin dan lainnya.

\section{Lama bertahan tidak merokok}

"saya bisa bertahan selama 5 jam tidak merokok”...... (Informan 1A)

"kurang lebih saya tidak merokok sekitar satu setengah jam, karena ketemu teman dan ngasih rokok"...... (Informan 1B)

"hampir 6 jam saya tidak merokok setelah terapi, masih merasa mual dan tidak enak merokok"... (Informan 1C)

"saya sebetulnya bisa berhenti total, ini sudah seharian tidak merokok tetapi saya buka warung kopi takut pelanggan tidak pada beli jadi saya merokok lagi, walaupun merasa tidak enak pertama kali merokok kembali"... (Informan 1D) 
Berdasarkan hasil wawancara dari ke 4 informan, untuk lama bertahan tidak merokok setelah di terapi berbeda-beda. Ada yang mengatakan 5 jam, 1,5 jam, 6 jam bahkan ada yang mengatakan seharian atau kurang lebih 8 jam sanggung tidak merokok.

\section{Jumlah batang rokok setiap hari}

"Biasanya sehari saya habis 1 bungkus, beberapa hari ini sebungkus bisa habis selama 3 hari, ketika habis makan saja atau kumpul sama teman-teman"...... (Informan 1A)

"menurun sekali saya sekarang jarang merokok, ketika cuaca dingin saja dan sekarang kalau dirumah tidak mau merokok"...... (Informan 1B)

"ada penurunan walupun masih merokok, biasanya sehari hampir sebungkus. Sekarang paling sehari 3-4 batang saja"... (Informan 1C)

"Saya sudah nyandu merokok,sejak dari SMA sudah puluhan tahun, apalagi saya punya usaha warung kopi biasanya habis 2 bungkus sehari, sekarang sudah berkurang dirumah sudah jarang merokok"... (Informan 1D)

Berdasarkan hasil wawancara dari ke 4 informan, untuk jumlah batang rokok yang di hisap setiap hari berbeda-beda setelah terapi, tetapi semuanya mengatakan mengalami penurunan dalam jumlah batang rokok yang di isap.

\section{PEMBAHASAN}

Menurut Notoatmodjo (2012) perilaku manusia adalah semua tindakan atau aktivitas dari manusia itu sendiri yang mempunyai bentangan yang sangat luas, baik yang dapat diamati langsung, maupun yang tidak dapat diamati. Dari segi biologis, perilaku adalah suatu kegiatan atau aktivitas organisme (makhluk hidup yang bersangkutan). Sedangkan dari segi kepentingan kerangka analisis, perilaku adalah apa yang dikerjakan oleh organisme tersebut baik dapat diamati secara langsung maupun tidak langsung.

Terkait dengan penelitian ini yaitu Pengalaman Perokok dalam terapi berhenti merokok dengan metode Spiritual Emotional Freedom Technique (SEFT) di Desa Cipanjalu Kabupaten Bandung Tahun 2019, bahwa kebiasaan merokok informan sebelum dilakukan terapi metode SEFT yaitu sebagian besar responden adalah Perokok Berat dimana merokok merupakan suatu aktivitas / kegiatan membakar rokok dan kemudian menghisapnya serta menghembuskannya keluar melalui hidung dan atau / mulut, dengan tujuan untuk mendapatkan sebuah kenikmatan tertentu, serta dapat menimbulkan asap yang dapat terhirup oleh orang orang disekitarnya. Perokok biasanya sangat menikmati dan merasakan kenyamanan yang pada akhinya menjadi kecanduan bila tidak merokok. Dalam sebatang rokok non filter, terdapat pula hingga 3 miligram nikotin yang dapat menginduksi ketergantungan pengguna rokok, hingga 500 mikrogram.

Hal ini sesuai dengan jurnal penelitian sebelumnya oleh Retno Rusdjiati dan Riana Mashar tentang Efektifitas Metode SEFT guna meminimalisasi Kebiasaan Merokok di 
kalangan pekerja Home Industry yaitu, merokok sudah menjadi kebutuhan untuk meningkatkan semangat kerja, menghilangkan kejenuhan, kepenatan dan rasa kantuk. Menurut hasil survey Jobstreet (2012) terhadap 3485 responden sebanyak 74,6 persen karyawan merokok pada jam kerja, 58,1 persen menyatakan bahwa merokok pada jam kerja dapat mempengaruhi kinerja perusahaan. ${ }^{15}$

Berdasarkan hasil wawancara dengan informan didapatkan adanya reaksi dari terapi metode SEFT yaitu bahwa merokok adalah suatu aktivitas yang tidak menyenangkan dimana respon setelah terapi merasakan adanya pahit di lidah, panas pada bibir dan tenggorokan serta asap rokok yang membuat perasaan ingin muntah, bahkan ada sebagian yang menyatakan bahwa pada saat terapi, rokok yang dihirup seperti bau apek.

Menurut hasil wawancara peneliti dengan informan, pada saat proses terapi beberapa responden merasakan pahit di lidah, panas di tenggorokan ketika sedang dilakukan tapping. Hal ini sesuai dengan tahapan terapi SEFT yaitu dengan cara melakukan Set Up: menekan titik nyeri didada sebelah kiri (sore spot) atau ditangan kiri atau kanan (karate chop), dilanjutkan dengan mengucapkan kalimat set up (doa) yang sesuai dengan masalah masing-masing dengan khusyu' dan sepenuh hati sebanyak 3 kali. Pada tahap ini adanya suatu kepasrahan dan kerelaan dari sebuah pengaharapan doa kepada Allah SWT untuk melepaskan rasa ketidakmampuan dalam alam bawah sadar.
Langkah selanjutnya adalah Tune In yaitu Merasakan rasa sakit yang diderita, kemudian pusatkan pikiran kita kepada rasa sakit itu, sembari mulut dan hati berdoa:" Ya Allah saya ikhlas menerima sakit saya ini dan saya pasrahkan kesembuhan saya pada-Mu”. Untuk masalah emosi, Tune In dilakukan dengan cara:

Membayangkan peristiwa yang dapat membangkitkan emosi negatif yang dimaksud. Kemudian ketika emosi negatif tersebut muncul (marah, sendih, takut dsb.) mulut dan hati berdoa: Ya Allah saya ikhlas menerima perasaan saya ini, saya pasrahkan pada-Mu ketenangan hati saya.

Langkah terakhir adalah Tapping Sambil terus melakukan Tune In, mulai dilakukan langkah ke-3, Tapping. Tapping adalah mengetuk ringan dengan dua ujung jari (jari telunjuk dan jari tengah) pada titik-titik kunci dari „The Major Energy Medians". Jika kita stimulasi titik-titik energy tersebut dengan ketukan ringan 2 jari akan menetralisisr gangguan energy tubuh, sehingga akhirnya masalah emosi atau fisik yang dialami akan teratasi.

Jumlah titiknya ada 9 untuk versi singkat dan ditambah lagi menjadi 18 untuk versi lengkap. Keras/lembutnya ketukan disesuaikan dengan penderita. Untuk versi lengkap, di titik yang ke 18 kita melakukan 9 gamut procedure, setelah itu balik tapping lagi ke titik pertama hingga titik ke 17.

Setelah selasai satu putaran tapping versi singkat atau lengkap, selalu kita akhiri dengan 
menarik nafas panjang sambil mengucapkan syukur. Sementara itu dilihat dari jumlah batang rokok yang di hisap setiap hari terjadi penurunan jumlah batang rokok. Hal ini sesuai dengan teori metode SEFT dalam mengelola pentingnya system energy tubuh yaitu, dalam proses terapi hanya dengan menggunakan ketukan ringan dengan ujung jari (tapping) pada daerah tubuh tertentu. Dengan eksperimen ini, dr Callahan telah banyak membantu pasiennya sembuh dari berbagai masalah psikologis dengan sangat cepat (dalam hitungan menit), dengan penemuan ini akhirnya disimpulkan bahwa Penyebab segala macam emosi negative adalah terganggunya sistem energy tubuh.

SEFT langsung berurusan dengan "gangguan sistem energy tubuh" untuk menghilangkan emosi negative itu (tidak perlu membongkar ingatan traumatis masa lalu). Bisa dikatakan SEFT melakukan "Short Cut" dengan memotong mata rantai di atas tepat di tengah-tengahnya. Cukup selaraskan kembali sistem energy tubuh kita, maka emosi negative yang kita rasakan akan hilang dengan sendirinya.

Seminggu setelah dilakukan terapi SEFT ada penurunan signifikan dalam jumlah batang rokok yang dihisap, seminggu setelah terapi kedua pun ada penurunan signifikan dalam jumlah batang rokok. Hal ini senada dengan hasil penelitian Hastuti (2017) bahwa nilai rata-rata yang diperoleh sesudah terapi sebesar 5,036 dan nilai standar deviasi yang diperoleh adalah sebesar 3,369 , dan nilai $\mathrm{p}$ - value yang diperoleh dari hasil uji Wilcoxon sebesar 0,000, angka tersebut lebih kecil dari 0,05.

Lebih lanjut dikatakan bahwa dari 20 orang responden ada 2 responden yang menunjukan hasil kenaikan setelah terapi SEFT kedua, hal ini disebabkan karena niat dari informan untuk berhenti merokok belum kuat, dimana kebiasaan merokok ini seringkali dipengaruhi oleh teman, lingkungan sekitar yang kurang mendukung, sehingga efektifitas terapi SEFT masih kurang dalam meminimalisasi jumlah batang rokok yang dihisap.

Hal ini sesuai dengan Teori Perubahan Perilaku TTM (Transtheorical Model) dimana pada tahap Contempelation Tahap ini adalah tahap dimana individu telah memiliki kesadaran akan problem yang dihadapinya dan mulai berpikir untuk itu. Namun pada tahap ini, individu belum membentuk komitmen untuk segera mengubah perilaku lamanya. Individu masih menimbang-nimbang pro dan kontra dalam mengubah perilakunya agar menjadi lebih sehat. Pada tahap ini tekad yang kuat dalam hati dan pikiran menjadi modal utama dalam perubahan Perilaku kearah lebih baik.

\section{KESIMPULAN}

Berdasarkan hasil penelitian dan pembahasan, maka dapat disimpulkan sebagai berikut:

1. Berdasarkan respon atau reaksi saat dilakukan terapi berhenti merokok 
ditemukan bahwa adanya reaksi yang hampir sama yaitu rasa pusing, mual, muntah, pahit di lidah dan tenggorokan dan rokok terasa hambar.

2. Berdasarkan keinginan merokok setelah dilakukan terapi berhenti merokok bahwa ditemukan semuanya mengalami penurunan rasa keinginan untuk merokok kembali. .

3. Berdasarkan lama lama bertahan tidak merokok setelah di terapi berbeda-beda. Ada yang mengatakan 5 jam, 1,5 jam, 6 jam bahkan ada yang mengatakan seharian atau kurang lebih 8 jam sanggung tidak merokok.

4. Berdasarkan jumlah batang rokok yang dihisap setelah dilakukan terapi berhenti merokok bahwa ditemukan jumlah batang rokok yang di hisap setiap hari berbeda-beda setelah terapi, tetapi semuanya mengatakan mengalami penurunan dalam jumlah batang rokok yang di hisap.

\section{SARAN}

Masyarakat diharapkan Membuat lingkungan bebas asap rokok dengan adanya komitmen bersama di lingkungan RW untuk membuat kawasan lingkungan bebas asap rokok.

\section{DAFTAR ISI}

1. World Health Organization. 2013. WHO Report On The Global Tobacco Epidemic 2013. Geneva : WHO

2. Tobacco Atlas. (2015). Cigarette Use Globally. Diakses pada 18 November 2017, dari http://www.tobaccoatlas.org/topic/cigar ette-use-globally/

3. Kemenkes RI. (2016). Perilaku Merokok Masyarakat Indonesia. Pusat Data dan Informasi. Jakarta.

4. Kemenkes. (2013). Rencana Strategis Kementerian Kesehatan Tahun 2010 2014. Jakarta.

5. Kementrian Kesehatan RI. (2011). Pedoman Pembinaan Perilaku Hidup Bersih dan Sehat. Jakarta.

6. STIKes Dharma Husada Bandung. 2018. Laporan Kegiatan Pengalaman Belajar Lapangan Prodi Sarjana Kesehatan Masyarakat. Bandung : Prodi IKM STIKes DHB

7. STIKes Dharma Husada Bandung. 2019. Laporan Kegiatan Pengalaman Belajar Lapangan Prodi Sarjana Kesehatan Masyarakat. Bandung : Prodi IKM STIKes DHB

8. Dinas Kesehatan Kabupaten Bandung. 2017. Peraturan Daerah (PERDA) Nomor 13 tahun 2017 tentang Kawasan Tanpa Rokok (KTR) di Kabupaten Bandung. Bandung. Dinkes Kab. Bandung

9. Ahmad Zaini Zainuddin (2015). Spiritual Emotional Freedom Technique (SEFT) for Healing Succes Happines Greatness. Jakarata

10. Ahmad Zaini Zainuddin (2013). Www.LoGos.co.id Seft For Healing. Sefter Handbook - 2nd edition

11. Nototoatmodjo, S. (2010). Ilmu Perilaku Kesehatan. Jakarta; Rineka Cipta

12. Notoatmodjo ，S. (2013). Pendidikan dan Perilaku Kesehatan. Jakarta : Rineka 
JURNAL SEHAT MASADA VOLUME XIII NOMOR 2 Juli $2019 \quad$ ISSN : 1979-2344

13. Maleong. 2007. Metode Penelitian Kualitatif. Jakarta: EGC

14. Notoatmodjo, Soekidjo. 2012. Metodologi Penelitian Kesehatan. Jakarta:

PT Rineka Cipta.
15. Retno Rusdjijati, Riana Mashar (2014) Efektifitas Metode SEFT Guna Meminimalisasi Kebiasaan Merokok di Kalangan Pekerja Home Industry,Seminar Nasional IENACO; ISS 